\title{
Migrating in the Medieval East Roman World, ca. 600-1204
}

\author{
Yannis Stouraitis
}

The movement of groups in the Byzantine world can be distinguished between two basic types: first, movement from outside-in the empire; second, movement within the - at any time - current boundaries of the Constantinopolitan emperor's political authority. This distinction is important insofar as the first type of movement - usually in form of invasion or penetration of foreign peoples in imperial lands - was mainly responsible for the extensive rearrangement of its geopolitical boundaries within which the second type took place. The disintegration of the empire's western parts due to the migration of the

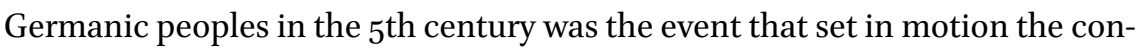
figuration of the medieval image of the East Roman Empire by establishing the perception in the eastern parts of the Mediterranean that there could be only one Roman community in the world, that within the boundaries of authority of the Roman emperor of Constantinople. ${ }^{1}$

From that time on, the epicentre of the Roman world shifted toward the East. The geopolitical sphere of the imperial state of Constantinople included the broader areas that were roughly circumscribed by the Italian peninsula in the west, the regions of Mesopotamia and the Caucasus in the east, the NorthAfrican shores in the south, and the Danube in the north. ${ }^{2}$ The Slavic settlements in the Balkans and the conquest of the eastern provinces by the Muslims between the late-6th and the late-7th century were the two major developments that caused a further contraction of east Roman political boundaries, thus creating a discrepancy between the latter and the boundaries of the Christian commonwealth that had been established in the east in the course of late antiquity. ${ }^{3}$

This new geopolitical status quo created new conditions regarding the movement of people and groups within the Empire. From a legal-political viewpoint, internal migration needs to be identified with movement within

1 Stouraitis, "Reinventing Roman Ethnicity", p. 72.

2 Haldon, The Palgrave Atlas of Byzantine History, pp. 22-67.

3 Fowden, Empire to commonwealth.

(C) YANNIS STOURAITIS, 2020 | DOI:10.1163/9789004425613_006

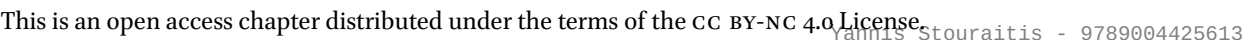


the -at any time current- boundaries of the imperial office's enforceable political, military, and economic authority. With respect to that, the fact that large parts of formerly Roman territories and Christian-Roman subjects were left outside the limits of this authority after the mid-7th century while maintaining - especially in the case of the Chalcedonian Christians ideological bonds with the imperial power of Constantinople, ${ }^{4}$ calls for a more flexible approach to the phenomenon of movement in the cultural context of the eastern Christian-Roman Oecumene. As we shall see below, if the Islamic conquest left a large part of Christian populations of various doctrines outside the contracted limits of imperial authority, these populations functioned eventually as a pool from which the imperial power of Constantinople could draw human resources from outside its current borders and resettle them on territory under its authority. This kind of movement had indeed very little to do with migration of culturally foreign populations into the empire, since the migrants' Christian identity hardly made them more foreign in their new region of settlement than any other group of Christians that migrated from one part of imperial territory to another by order of the imperial government or by their own initiative.

Departing from such a flexible approach to the movement of groups within and from outside-in the at any time current imperial boundaries after the 7 th century, I will use as a starting point for my analysis the generic typological distinction between involuntary and voluntary migration. ${ }^{5}$ The main criteria to distinguish movement of groups will be: (1) whether their long-term or permanent change of residence was forced by another actor or impelled by some natural factor, or (2) whether it took place due to the individual initiative and interests of the group. Diagram 5.1 represents an effort to schematize relevant ideal types.

Based on this analytical framework, the focus of the current paper will be on the different types of involuntary movement of groups in the geopolitical sphere of the imperial state of Constantinople in the period between c.6oo and 1204. As one may deduce from the diagram, involuntary migration consists of many different subtypes. In the Byzantine case, given the status of our sources, the major bulk of the information concerns migration of smaller or larger groups of people, which was forced upon the migrating subjects by war or state coercion. Warfare mainly caused two types of movement: first, deportation of populations that were taken captive by enemy forces and were either sold as slaves or resettled within the enemy's administrative borders, either for a longer period of time or permanently. Second, flight of populations from their

4 Haldon, The Empire that would not die, pp. 79-119.

5 Oliver-Smith/Hansen, "Involuntary migration and resettlement: causes and contexts". 


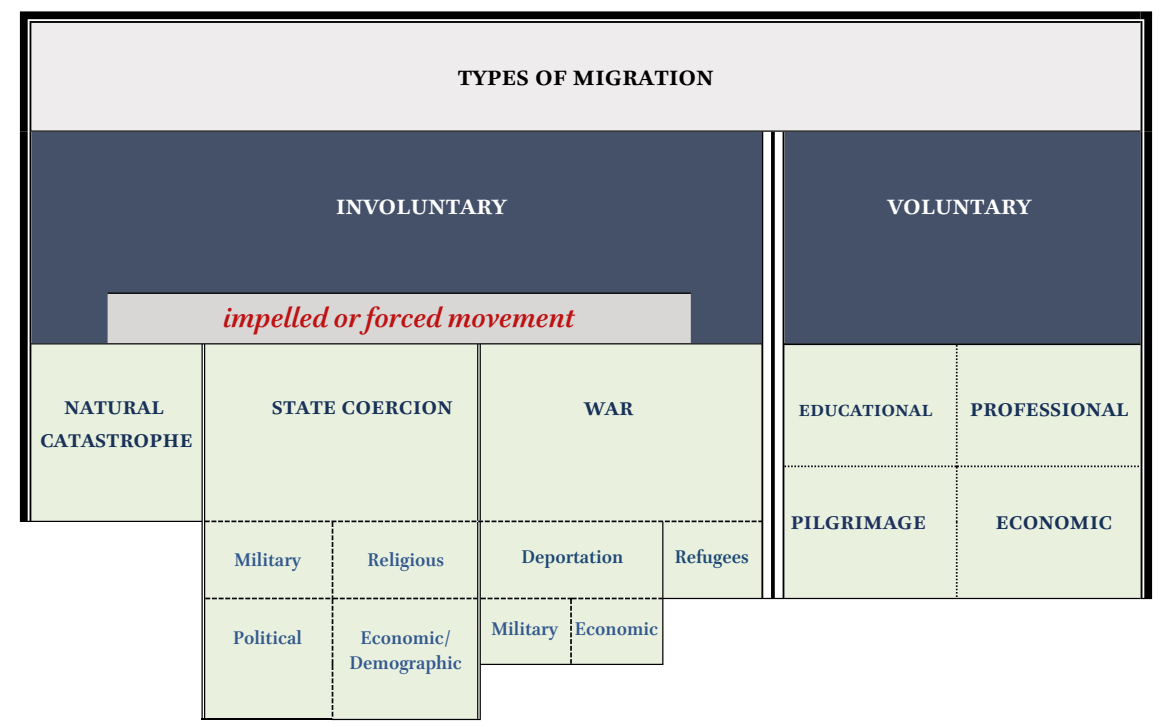

DIAGRAM 5.1 Categorisation of the types of migration and their causes discussed in Byzantine sources

homelands in order to seek refuge (for a longer period of time or permanently) in areas not affected by enemy raids or conquest. State coerced migration, on the other hand, refers to the initiative of the imperial government to resettle subject populations within the boundaries of the empire in order to meet various needs and problems of demographic, economic and/or military character as well as for the purpose of enhancing cultural-religious homogeneity in certain regions.

The here suggested ideal subtypes of forced migration by the state should not be approached as mutually exclusive, since one type may very well include elements of all the others. Moreover, this kind of migration also concerns coercive actions in neighbouring states that forced parts of their subject populations to seek refuge in Byzantine territory. Besides war and state coercion a less documented but equally important subtype of impelled movement was the one caused by natural phenomena, such as plague, draught, flood etc. that occasionally forced groups of people to abandon their home places in search of better conditions of subsistence.

Given that forced migration has probably been the most studied aspect of movement within the medieval East Roman Empire, especially for the period between the seventh and the mid-9th century, ${ }^{6}$ my aim here is to take a closer look at the development of the phenomenon in the period under scrutiny in

6 Ditten, Ethnische Verschiebungen; Charanis, "The Transfer of Population as a Policy in the Byzantine Empire", passim. 
order to discern various patterns and their ideological, political-economic, military and cultural connotations.

The 7 th century admittedly represents a period of extensive transformation of the Roman Empire of Constantinople, the main trigger of which was the invasion and settlement of foreign peoples on imperial soil. After the end of Justinian I's reign, whose expansionary wars had re-established for the last time the Roman dominion around the shores of the Mediterranean, the Empire received serious blows in the West, the most important being the invasion of the Lombards in Italy from 568 onwards. By the beginning of the 7 th century, the imperial power had once again been deprived of large parts of the Italian peninsula that had come under Lombard rule, its authority being confined to the regions of Ravenna, Apulia and Calabria, and Sicily. In the East, the short-term occupation of Roman provinces by the Persians, which Heraclius was able to reverse in the late 620s, prepared the ground for the first phase of the early Islamic expansion under the Rashidun Caliphs between 632 and $661 .^{7}$

The loss of territories to the Slavs in the Balkan Peninsula as well as the loss of the eastern provinces due to the consecutive Persian and Arab conquests unavoidably led to a large number of people becoming refugees. These people left the conquered areas in the face of the enemies' advance in order to resettle in other parts of the contracted territory that had remained under imperial authority. ${ }^{8}$ The sources rarely offer detailed or, for that matter, reliable information about the numbers of people that relocated or about the attitude of different social groups. Nonetheless, the existing evidence indicates that the imperial elite of service, the clergy and the monastic communities, as well as the army represent those social groups whose members were the first to abandon the areas that fell under Persian and later under Muslim rule.

For instance, the major Byzantine defeats from the Arabs on the battlefield were followed by the withdrawal of the eastern armies in Asia Minor, the remaining parts of which were resettled within Byzantine Anatolia. This set in motion the emergence of a new military organization by the early-8th century, which was based on large territorialized military commands, the so-called

Haldon, Byzantium in the seventh century, pp. 32-56; idem, The Empire that would not die; Kaegi, Byzantium and the early Islamic Conquests.

8 On the Slavic settlement, cf. the chapters of Johannes Koder and Florin Curta in this volume; on the eastern provinces cf. the chapter of Panagiotis Theodoropoulos. 
strategiai. ${ }^{9}$ Moreover, it is reported that one of Emperor Heraclius' actions against the Muslim advance was to evacuate the populations of the areas between Antioch and Tarsus leaving a no-man's-land behind. ${ }^{10}$ The imperial power was, also, capable of organizing the evacuation of people from cities under siege when these had access to the sea, as the case of the inhabitants of the besieged city of Tripolis on the Syriac coastline demonstrates. In the year 645 , these dispatched letters to emperor Constans II asking him to send a fleet that would help them flee the city in case that no military reinforcements could be sent from the imperial centre to relieve them from Muslim pressure. Indeed, the emperor reacted to the request and an imperial fleet evacuated those that wanted to leave the city, relocating them to an unknown safer place within the empire."1

The interior of Asia Minor and Cyprus seem to have been the main areas that received the bulk of the refugees from the conquered provinces in the east. The Muslim conquerors of the eastern regions usually proceeded with a common pattern toward the indigenous population. The inhabitants of Byzantine cities that surrendered were given the choice to remain as subjects of the Muslims paying the poll tax or to seek refuge to Byzantine territory if they so wished. ${ }^{12}$ In some cases, populations that had fled their hometown in the face of the Muslim advance were later able to make an agreement with the conquerors and return, as the case of the Syrian city of Laodikeia demonstrates. ${ }^{13}$

In the Balkans, the Slavic settlement created a fairly different situation. The actual portion of territory that various Slavic tribes occupied remains a debated issue among scholars. The dominant view is that up to the mid-7th century Constantinople gradually lost administrative control over the largest part of the peninsula, with the Slavs occupying the mainland as far south as the Peloponnese and leaving only small strips of territory, mainly on the eastern Greek coastline, alongside some important urban centres such as Thessaloniki in the north or Athens in the south under Byzantine authority. The result of this was that large parts of the indigenous population abandoned their homelands and migrated in two main directions: The one was southern Italy; a movement concerning mainly the inhabitants of the western parts of the Balkan peninsula, in particular of western Greece. The other direction was towards those strips of

$9 \quad$ Brubaker/Haldon, Byzantium in the Iconoclast Era, pp. 726-728.

10 Kaegi, Heraclius, pp. 244-245.

11 Al-Baladuri, The Origins of the Islamic State, p. 128.

12 Ditten, Ethnische Verschiebungen, p. 55. Similar practices were employed by the Byzantines during their reconquest of the east in the tenth century, see Leon Diakonos, Historia, ed. Hase, pp. 6o, 161.

13 Hitti, The Origins of the Islamic State, p. 135. 
land and in particular those urban centres on the eastern coastline of Greece as well as towards the islands of the Aegean.

The so-called chronicle of Monemvasia - despite its debated credibility ${ }^{14}$ provides plausible indications about the potential locations of resettlement of the indigenous population of medieval Greece as a result of the Avar and Slavic incursions. According to its author:

(the Avars) subjugated all of Thessaly Epirus, Attica and Euboea. They made an incursion also in the conquered it by war, and, destroying and driving out the noble and nations settled in it themselves. Those among the former escaping from their blood-stained hands dispersed themselves here and there. The city of Patras emigrated to the territory of Rhegium in Calabria; the Argives to the island called Orobe; and the Corinthians to the island called Aegina. The Lakones too abandoned their native soil at that time. Some sailed to the island of Sicily and are still there in a place called Demena, call themselves Demenitae instead of Lacedaemonitae, and preserve their own Laconian dialect. Others found an inaccessible place by the seashore, built there a strong city which they called Monemvasia because there was only one way for those entering, and settled in it with their own bishop. Those who belonged to the tenders of herds and to the rustics of the country settled in the rugged places located along there and have been lately called Tzakonitae..$^{15}$

For the inhabitants of Patras at the northwestern corner of the Peloponnese sailing towards Byzantine Calabria in the southern part of the Italian peninsula seems like the easiest way to flee the Slavic influx. Their relocation there seems to be verified by a commentary in one of the writings of Arethas, bishop of Caesarea, in the early-1oth century. Arethas states that a number of those migrants' offspring returned from south Italy to their (and his own) homeland, Patras, at the beginning of the 9th century. ${ }^{16}$ The inhabitants of Laconia, an area in southeastern Peloponnese, are also presented to have sailed to Sicily. The information that another part founded the naturally protected fortresstown of Monemvasia at the southeastern shore of the peninsula has been shown to be inaccurate, since the site already existed before the Slavic inroads. ${ }^{17}$

14 Charanis, "The Chronicle of Monemvasia", 141-166.

15 Chronicle of Monemvasia, ed. Dujcev, pp. 12-16. Engl. trans. in Charanis, "The Chronicle of Monemvasia", 148.

16 Anagnostakis/Kaldellis, "The textual sources of the Peloponnese", 105-115; Charanis, "The Chronicle of Monemvasia", $15^{2}$.

17 Haldon, Byzantium in the seventh century, p. 44, n. 10. 
Nonetheless, this report could be considered as an indication for migration of shorter distance within the same region from a less safe homeland to a new one that was better defensible and inaccessible to the invaders. This is verified by another report about the inhabitants of Corinth who seem to have sailed to the island of Aegina in the Saronic Gulf in order to put the sea between them and the invaders. The conquest of Sicily by the Arabs in the gth century triggered a similar phenomenon of regional migration of Byzantine populations from the island to Calabria but also towards Greece, where imperial authority had been rehabilitated for the most part. ${ }^{18}$

Short or longer distance migration was more often than not the result of an area becoming repeatedly a victim of enemy raids. The frontier zone that emerged between the empire and the caliphate in the course of the $7^{\text {th cen- }}$ tury was subject to yearly raids up to the 1oth century. Local populations were often obliged to abandon their homes and seek for a safer place of residence in the interior. A typical example is the reported mass withdrawal of local populations from the border areas with the Caliphate in $716 / 7$ in the face of a large Muslim invasion that culminated in the second Arab siege of Constantinople. ${ }^{19}$

Arab naval warfare, which often acquired the form of piracy against the islands and the coastal areas of the Aegean Sea, was another reason for populations in these areas to decide to abandon their homelands in search of a safer place. The life of St Luke of Steiris provides an interesting insight into this kind of movement. According to his biographer, the ancestors of the saint originated from the island of Aegina, which they, along with the rest of its inhabitants, were forced to abandon due to the continuous raids of the Muslims. They migrated to various regions such as Attica, the Peloponnese, and Boeotia, probably in the reign of Basil I (867-886). The saint's family arrived at a place called Chrysos at the gulf of Itea, wherefrom they were once again forced to leave due to an Arab naval raid. Finally, they settled in a nearby location, called Kastorion. ${ }^{20}$

If this type of forced migration within the borders of the empire should be considered typical for the most part of the period between the 7 th and the 1oth centuries, the next large wave of refugees due to warfare seems to have taken place during the Seljuk occupation of large parts of Asia Minor in the late-11th century. The nature of the advance and settlement of Seljuks and Turkomans in Asia Minor did not have a similar sweeping character as the Islamic conquest

18 McCormick, "The Imperial Edge", p. 33.

19 The Seventh Century in the West-Syrian Chronicles, p. 62.

$20 \quad$ Life of St Loukas of Steiris, ed. Sophianos, p. 4. 
of the eastern provinces some centuries earlier, since the newcomers seem to have interpenetrated imperial structures and to have established various new principalities in Anatolia in interaction with the local element or next to it. ${ }^{21}$ The sources provide little specific information on groups of refugees from the areas that came under Turkish control after the 1170s. One rather finds typical reports on the devastating effects of Turkish raids and the occupation of urban sites throughout the long 12th century. Once again it seems that the main social groups that opted for migration in the course of the Turkish settlement where the landed aristocracy and the clergy. ${ }^{22}$

Bearing this in mind, statements such as the one by Odo of Deuil who as a participant in the Second Crusade reported in the mid-12th century that the Turks had driven the indigenous population out of the largest part of Asia Minor need to be approached with caution. ${ }^{23} \mathrm{~A}$ mass withdrawal of Roman populations from central and eastern Anatolia can hardly be testified. Moreover, the population of cities in western Anatolia that were ruined by Turkish raids seems to have opted for short distance migration towards safer places in adjacent regions which, of course, may have included those islands of the Aegean close to the coast of Asia Minor. With regard to the devastation caused to the cities of the coastline between Smyrna and Attaleia by the Turks during the reign of Alexios I, Anna Komnene reports that the emperor sought to revive the ruined cities and bring back their emigrated inhabitants. ${ }^{24}$ Moreover, during the campaign of Alexios Komnenos against Ikonion in central Anatolia in 1116 many of the Christians that lived under the Turks found an opportunity to follow the emperor's army and seek refuge in imperial territory. ${ }^{25}$ Choniates provides some insight into short distance migration when he reports on the surrender of the besieged city of Dadibra (today Safranbolu in north-central Anatolia) to the Turks in the year 1196. The author states that the city inhabitants were forced by the new masters to migrate to other provinces and cities, whereas some of them built wooden huts near their native city with the permission of the Turks and sustained the yoke of slavery because they could not bear to stay away from their cherished homeland. ${ }^{26}$

The sack of Constantinople by the Crusaders in 1204 was the culminating event of this period and was marked by the migration of a large number of the imperial city's inhabitants. Choniates as an eyewitness and a victim of these

\footnotetext{
21 Beihammer, Byzantium and the Emergence of Muslim-Turkish Anatolia, pp. 169-304.

22 Vryonis, The Decline of Medieval Hellenism, pp. 194-229.

23 Odo of Deuil, De profectione Ludovici viI in orientem, ed. Berry, pp. 86-69.

24 Anna Komnene, Alexias, XIV 1, 2, ed. Reinsch/Kambylis, pp. 424-425.

25 Ibid. XV 7, 1-2 ed. Reinsch/Kambylis, p. 481.

26 Choniates, Historia, ed. van Dieten, p. 475.
} 
events provides evidence of that movement when he describes how he with his family followed a group of Constantinopolitans consisting of members of the clergy including the patriarch, high-ranking officials, and commoners. These decided to depart from the conquered city five days after its fall out of fear for the plundering conquerors. The procession broke out on foot and moved towards the nearby town of Selymbria. ${ }^{27}$ From the account, we may conclude that Choniates' family settled there for about two years before returning in June 1206 to Constantinople wherefrom they departed once again after sixth months for Nicaea. ${ }^{28}$ Their relocation to the city that had come under the control of Theodoros Laskaris who created a new imperial court there was obviously related to Choniates' need to reclaim his higher social status and position, which he had lost after the sack of the imperial city. However, he hardly received the attention he expected as his embittered narration of the fate of his family demonstrates. ${ }^{29}$

If warfare was responsible for large waves of refugees from the empire's lost territories as well as from regions constantly affected by enemy raids, it was also the cause of another type of forced migration, namely the deportation of populations by enemy forces. Enemy attacks on imperial soil or Byzantine campaigns beyond the imperial frontier were more often than not related with the capture and forced relocation of considerable numbers of people. The deportation of the inhabitants of large towns or smaller settlements under the threat of arms could be of two types: The first type was enslavement resulting from women, children as well as surviving soldiers being captured, brought to and sold on the slave market. This led to their relocation -often for a life timefrom their home place to foreign territories. ${ }^{30}$ The second type refers to the resettlement of groups of people as freemen from their region into enemy territory, where this population was settled and incorporated into local life and state structures.

The capture and deportation of the inhabitants of Byzantine cities, villages, and smaller settlements was a recurrent result of Muslim raiding into imperial

27 Ibid., p. 593, cf. also p. 612 about elite members fleeing the city with emperor Alexios III who sought refuge to Larissa in central Greece.

28 Ibid., p. 635 .

29 Simpson, Niketas Choniates, pp. 22-23.

3o On slavery in the eastern Mediterranean, see the chapter of Youval Rotman in this book. 
territory in the period between the mid-7th and the 1oth century. A main goal of such raiding activity was the accumulation of plunder and the capture of prisoners of war which was quite profitable, since these were sold on the slave market earning their sellers a great deal of money. There are numerus reports in the sources about Muslim armies that invaded Byzantine territory and were able to withdraw with great booty among which where captive civilians. ${ }^{31}$ A characteristic case of forced removal of populations through captivity and enslavement from both sides represent the events of the years $837-838$. The Byzantine army of emperor Theophilos conducted a campaign on Muslim soil in the course of which it captured and destroyed the cities of Aramosata and Sozopetra taking one thousand prisoners that were transferred into the empire. ${ }^{32}$ In the following year, Caliph al-Mu'tasim retaliated by capturing the city of Amorion, the birthplace of the empire's reigning dynasty. The Muslims slaughtered the largest part of the city's defenders and the largest part of the civilians, mainly women and children, was taken captive. Al-Tabari reports how a slave market was organized in situ and many of the captives were sold to slave traders that carried them away. ${ }^{33}$ Those not sold, among whom were the high-ranking officials of the Byzantine army and local notables, were transferred into the caliphate where they were kept as prisoners.

If such forced migration often led to the permanent resettlement of the captives, sometimes these could be given the chance to return to their homelands after several years through an arranged exchange of war prisoners between the empire and the caliphate. ${ }^{34}$ Seven years after the events of Amorion an exchange of prisoners of war was organized between the two powers. According to the Arab sources, the caliph al-Wathiq had to buy off the freedom of many Byzantine prisoners of war that had been sold as slaves in the caliphate in order to use them to match the number of Muslim prisoners that the Byzantines offered for the exchange. ${ }^{35} \mathrm{~A}$ similar return of Roman prisoners of war that had been deported from Sicily by the Muslims and had spent some years in North Africa is reported by Leo the Deacon in the reign of Nikephoros II Phokas

31 For the 7th and 8th centuries, see Lilie, Die Byzantinische Reaktion, pp. 57-195, esp. 194195; for the 11th and 12th see the references in Vryonis, The Decline of Medieval Hellenism, pp. 174-175. Bosworth, The History of al-Tabari, vol. XXXII, p. 93; cf. Codoñer, The Emperor Theophilos and the East, pp. 264-278.

33 Bosworth, The History of al-Tabari, vol. XXXII, pp. 116-117.

34 On such exchanges, see Rotman, Byzantine Slavery, pp. 33-39.

35 The History of al-Tabari, vol. XXIV, transl. Kraemer, pp. 39-40; Bar Hebraeus, The Chronography, ed. and trans. Budge, p. 140. 
$(963-969) \cdot{ }^{36}$ Byzantine military activity also led to the liberation of Roman subjects that had been dragged away from their homes as captives. In the reign of Michael IV, the Byzantine commander Leon Opos campaigned in Sicily and managed to cross back to Byzantine southern Italy with fifteen thousand Roman prisoners whom he dispersed to their homes. ${ }^{37}$

Besides imprisonment and enslavement, the deportation of populations by enemy forces could often have the form of resettlement and integration of the deported groups into the enemy state's structures. From the 7th century onwards, the Byzantine imperial power was very keen to follow this practice for various reasons such as dealing with demographic decline and strengthening its productive population and armed forces. Constans II was the first to conduct a campaign against the sklaviniai (territories under Slavic control) in the regions of Macedonia und Thrace in 658, in which he took a large number of captives that he resettled in Asia Minor, obviously as a new productive and taxpaying group of Roman subjects. ${ }^{38}$ Justinian II was the next emperor to campaign against Bulgars and Slavs in 688 . He subjugated a large number of those and transplanted them to Bithynia in north-western Asia Minor, where they were given land to settle and part of them was enrolled into the imperial army as a separate military corps. ${ }^{39}$

In the 8th century, Constantine v conducted similar forced transfers of populations from the frontier zone with the caliphate to the empire's European territory in Thrace. In 746, the imperial army campaigned against Germanikeia (Maras) in northern Syria. After the city's surrender, the emperor organized the transfer of the city's mainly Monophysite population to Thrace. ${ }^{40}$ Similarly, predominately Monophysite populations from Melitene und Theodosioupolis were transplanted by the same emperor to Thrace in 756 and $771 .^{41}$ In the latter case, the sources record the large number of 150,000 people. The emperor's son and successor Leo IV (775-780) conducted another transfer of Syriac Jacobites and Armenians to the same region. The imperial power's main goal with these movements seems to have been to strengthen demographically the region, which stood between the imperial city and the Bulgar territories. At the same time, it sought to deprive of large numbers of productive population those

\footnotetext{
36 Leo Diakonos, Historia, ed. Hase, pp. 76-77.

37 Skylitzes, Synopsis, ed. Thurn, p. 401.

38 Ditten, Ethnische Verschiebungen, pp. 209-211.

39 Ibid., pp. 220-223; Charanis, "The transfer of populations", p. 143.

40 Theophanes, Chronographia, ed. de Boor, p. 422; Nikephoros, Short History, ed. Mango, p. 62; Ditten, Ethnische Verschiebungen, pp. 179-180.

41 Ditten, Ethnische Verschiebungen, pp. 184-185, 192.
} 
areas in the eastern frontier zone, which the Byzantine army could not control.

The practice of deporting heretical Christian populations from territories under Muslim rule and resettling them into the empire raises the issue of the role of Christian identity in such transfers. Obviously, doctrinal and ethnocultural differences did not pose a serious obstacle for the resettlement of those populations in the empire's territorial core and their integration into the political body of imperial subjects. On the other hand, a shared Chalcedonian Christian identity made the deportation and resettlement of populations between different political entities easier, as the wars between the Bulgars and the Byzantines in the Balkans after the formers' Christianization demonstrate. Tsar Samuel conquered the city of Larissa in the early years of his war against Emperor Basil II when the emperor was still occupied with the rebellion of his general Bardas Skleros (976-979). The Bulgar leader transferred the city's population along with the relics of its patron St Achillios to Bulgar territory, where he recruited the men into his army and used them in his war against the Romans. ${ }^{42}$ Skylitzes reports that towards the end of the war Basil II liberated Roman populations that had been deported by the Bulgars and had been settled in the cities of Pelagonia, Prespa, and Ohrid. ${ }^{43}$

The Byzantines employed similar practices of deportation on the Balkan front. During the same war, Basil II conquered the fortress of Serbia in 1001 and had its inhabitants transferred to an unknown place, installing a Roman guard in the city. Furthermore, he invaded Thessaly and retook many fortresses before moving to besiege and conquer the strong fortress of Bodena (present-day Edessa) in northern Greece. The Bulgar inhabitants of all these fortresses were relocated to Boleron close to the Byzantine military base of Mosynopolis. ${ }^{44}$ After the conquest of the city of Moglena all men that could bear arms were resettled by the emperor to the region of Vaspurakan in the East. ${ }^{45}$ These practices of deportation were related with issues of military security and aimed at keeping newly subjugated populations quiescent by detaching them from their homelands.

The use of deported groups to strengthen demographically, economically, and militarily the imperial realm is testified in the 12th century as well. John II Komnenos (1118-1143) made a number of captives in his campaign against the

42 Skylitzes, Synopsis, ed. Thurn, p. 330.

43 Ibid., pp. 363.

44 Ibid., pp. 344-345. The same practice took place again in 1014 when the emperor had to conquer the city anew, which in the meantime had passed to Bulgar hands again, ibid. p. $35^{2}$.

45 Ibid. p. $35^{2}$. 
Serbs in 1123 and resettled them in Asia Minor where he gave them land, making them taxpaying subjects of the empire that were enrolled in his army. ${ }^{46}$ Similar deportations tool place in the opposite direction, that is, towards the lands of the empire's enemies. Choniates reports on a raid of the Turkish ruler of Ikonion Kaykushraw in 1198 when he captured the inhabitants of the cities of Karia and Tantalos along the Meander. These were resettled in the region of Philomelion. ${ }^{47}$

\section{State-Coerced Resettlement of Populations}

Besides migration as a consequence of military activity in the geopolitical sphere of the empire, the imperial state of Constantinople undertook planned relocations of subject populations within its own boundaries throughout this period. Such relocations mostly had a coercive character and were intended to satisfy various needs: demographic, economic, and military. Two basic types of relocation can be discerned here: the first concerns the relocation of populations that were already imperial subjects and the second groups outside the imperial realm that came in agreement with the imperial power that organized their settlement on imperial soil.

The first type of relocation points to the -by medieval standards- highly centralized function of the Byzantine state. The imperial government's ability to coercively resettle large numbers of its subjects within the borders of its authority was based on its monopoly of control over superior military power. In the period under scrutiny, emperor Justinian II was the first to organize the relocation of Roman subjects from the island of Cyprus to the regions of Cyzicus in Hellespont and of southwestern Asia Minor in 691. The main motive behind this forced transfer was the need of the imperial power to reduce the tributary population of those parts of Cyprus that had come under Arab economic control within the framework of the -much-debated-condominium of the two powers over the island. It seems to have been part of a larger plan of forced removals of groups organized by this emperor for military and demographic reasons (e.g. Slavs, Mardaites). ${ }^{48}$ The sources provide a nuanced approach to the character of the migration. Theophanes, for instance, highlights its coercive aspects whereas other sources point to its liberating character

46 Choniates, Historia, ed. van Dieten, p. 16.

47 Ibid., p. 594 .

48 Ditten, Ethnische Verschiebungen, pp. 308-317. 
from Muslim yoke. ${ }^{49}$ Military reasons seem to have led Emperor Tiberios III Apsimar to organize the return of the Cypriots to their homeland seven years later. ${ }^{50}$

The next major transfer of imperial subjects took place in the reign of Constantine $\mathrm{V}$ and the reasons were purely demographic. The large number of human losses as a result of the last wave of the plague that had broken out in $744 / 5$ and had lasted up to 748 caused the extensive depopulation of the imperial capital. The relocated populations came mainly from the regions of Greece and the Aegean islands, but perhaps also from eastern Asia Minor, whereas it remains debated whether the emperor's action took place right after the waning of the plague in 748 or in the year 755 when his military campaigns on the eastern front were marked by the forced transfer of Syrians and Armenians to Thrace. ${ }^{51}$ Nevertheless, the ethno-cultural and doctrinal identities of the populations that were resettled in Constantinople to revive demographically the imperial capital may have been mixed, consisting of Greek-speaking Chalcedonian Christians, and Monophysite Armenians and Syrians.

One of the most studied transfers of imperial subjects in the empire took place in the reign of emperor Nikephoros I (802-811). The imperial power transplanted an unknown but obviously considerable number of its subjects from Asia Minor to Greece. The first action took place in 806/7 and was of lesser scale, while the second and larger transfer occurred in 809. The organized character of this transfer is demonstrated by the fact that the affected population, which in its majority must have consisted of Greek-speaking Chalcedonian Christians, was forced to abandon its homelands by selling their properties and was relocated to those Slavicized areas of Greece that had recently come under imperial authority again. ${ }^{52}$ The emperor's goal was to strengthen the Greek-speaking Chalcedonian element in those newly reconquered areas that were dominated by Slavs. Moreover, it seems to have been related to a major administrative reform, namely the foundation of the notorious theme-system. As has been shown, contrary to the traditional views of scholarship the division of the empire in administrative units called the$m a t a$, in which a general undertook both military and civil authority, began in this emperor's reign. ${ }^{53}$ The relocation must, therefore, have involved a large number of families that had a military background and seems to have been

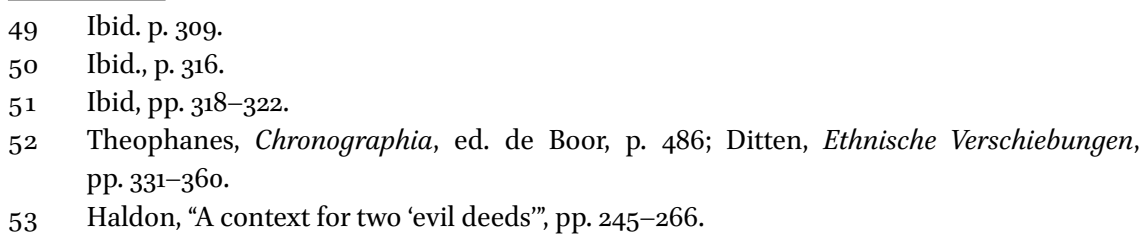


primarily intended to re-establish the imperial state's authority in the Balkans in military-political terms.

A similar case in which the main aim was to re-establish Roman militarypolitical authority along with an effort of re-Romanization of the affected areas is the relocation of groups of imperial subjects, consisting of Armenians and Rhomaioi (that is, Greek-speaking Chalcedonian Christians), to Crete in 961 after the reconquest of the island by general Nikephoros Phokas. ${ }^{54}$ The imperial power obviously aimed at strengthening the Christian element on the island that had been under Muslim rule since the 82os. The relocated families must have been given lands in order to strengthen the local productive population and thus, also, secure tax revenues from the island, as well as to provide new resources of local recruitment for its defence. That this state-sponsored process of re-Romanization mainly concerned the re-Christianization of the island's population is also demonstrated by the missionary activity of monks that were sent to the island to Christianize its islamicized inhabitants. ${ }^{55}$

As already argued above, in spite of the official attitude of the imperial state according to which Roman subjects should be orthodox (i.e. Chalcedonian) Christians, the imperial power did not hesitate to resettle groups of heretics into the empire's territorial core when demographic and military needs were to be met. The Paulicians represent another good point in case in this regard. These were a dissident group of imperial subjects of heretic doctrine that had created an autonomous principality in eastern Asia Minor in the mid-gth century before being militarily subjugated by Emperor Basil I (867-886). In the 1oth century, emperor John I Tzimiskes decided to resettle a large number of those Paulicians from the East to Thrace. There, they were given lands and inhabited fortresses in the context of the emperor's plan to reorganize the defence of the area in the face of the inroads of nomadic peoples, mainly the Pechenegs. ${ }^{56}$

Besides these organized removals of ethno-culturally and doctrinally diverse groups of Roman subjects, the imperial power of Constantinople controlled and directed the migration and settlement on imperial soil of various groups of people that came from the periphery or from outside the current imperial borders. One of the more prominent resettlements of such a group is that of the so-called Mardaites. The latter are generally considered to have

54 Leon Diakonos, Historia, ed. Hase, p. 28.

55 The Life of Saint Nikon, text, translation and commentary by D.F. Sullivan, Brookline, MA 1987 , pp. 83-87.

56 Skylitzes, Synopsis, ed. Thurn, p. 286; cf. Lilie, "Zur Stellung von ethnischen und religiösen Minderheiten in Byzanz", pp. 312-315. 
been a group of Monophysite Christians that enjoyed an autonomous status in the region of the Amanus Mountains in the Caliphate and were resettled to southern Asia Minor as a result of a peace treaty between Emperor Justinian II and the Caliph Abd al-Malik in $685 .{ }^{57}$

Theophanes the Confessor who is well-known for his bias towards Justinian II describes this resettlement as a grave political mistake because it deprived Byzantium of a competent military ally on the eastern frontier. ${ }^{58}$ According to a recent theory, however, the 12,00o Mardaites that came from the Caliphate may have been Byzantine deserters that had been settled in the areas of northern Syria, around Antioch and Cyrrhus, by the Muslims and were returned to the empire after the peace treaty. ${ }^{59}$ This means that their resettlement in the naval theme of Kibyrrhaiotai as oarsmen may have related to the fact that they had some previous military experience. Given that service in the navy was not popular among recruits, it may have represented a suitable way of reintegrating deserters into the imperial army in a disciplinary manner.

In the reign of Emperor Constantine v, it is reported that a large number of Slavs fled the Bulgar kingdom due to the change of regime there and sought refuge in the empire. Whether the Byzantine emperor encouraged this movement remains unclear, but he certainly received the Slavic population and organized its resettlement in Bithynia. The number of the refugees mentioned in the sources is very large (208,000 people) and has been a subject of debate, with more scholars tending to accept its credibility due to the fact that it is not a round number. ${ }^{60}$ If this comes any close to the true number of people that migrated, that makes it certainly one of the most spectacular peaceful relocations of this period, which must have decisively altered the character of the area of Bithynia in demographic and ethno-cultural terms.

Reasons of military concern urged the East Roman imperial power to accept and organize the settlement within its own territories of large military groups that fled the Caliphate in times of crisis. These were usually integrated into the imperial army, thus strengthening its ranks. Prominent examples are the case of the Khurramites, a contingent of 14,00o men that fled the Caliphate with their leader Nasr in 833. The reason for their migration was their participation in the failed rebellion of the Persian Babak against the Abbasids. Nasr and his men were given shelter by Emperor Theophilos who enrolled them into the

57 Ditten, Ethnische Verschiebungen, pp. 138-158.

58 Theophanes, Chronographia, ed. de Boor, p. 363.

59 Woods, "Corruption and Mistranslation".

6o Ditten, Ethnische Verschiebungen, pp. 83-88. 
empire's eastern forces as a tourma of the Armeniakon army. ${ }^{61}$ A similar case represented the Banu Habib tribe in the late-1oth century, the members of which fled from the region of Nisibis in Mesopotamia to the empire sometime after the fall of the emirate of Melitene in 934, probably in 941. Emperor Romanos I organized their settlement and integration into army structures in the eastern provinces through their Christianization. The 12,000 men were divided in various units and were used to garrison new themes on the eastern frontier. ${ }^{62}$

Settlements of outsiders as new imperial subjects were organized due to different reasons in the later period as well. The culmination of the empire's expansionary activity in the early-11th century involved the annexation of Armenian territories in the East. This caused the relocation into imperial territory of large groups of Armenians, mainly magnates with their large retinues. The latter were either motivated or forced to exchange Byzantine control over their lands with lands for settlement in Asia Minor and high-ranking imperial offices and titles. Prominent cases are that of the King of Vaspurakan, Senkerim-Yovhannes Arcruni, who migrated with all his followers in 1021/22 in Cappadocia, where he settled and became an imperial general with the title of patrician. His son also received the same office and titles. The same migrating route took the King of Ani Gagik II Bagratuni in 1044/45 and the King of Vanand or Kars Gagik-Abas in 1065/65. These and many others were settled in eastern Asia Minor with their retinues acquiring control of cities and imperial titles. ${ }^{63}$

The incursions of the Pechenegs into the empire from the mid-11th century onwards were related to a new kind of migration. In the course of these conflicts, the imperial power was often willing to come to terms with the invaders who often represented not plain armies but whole groups of people with elders, wives and children following the warriors. For instance, Emperor Constantine IX offered lands for settlement across the Danube to a group of 20,000 Pechenegs that fled to the empire under the leadership of Kegen in 1045 when the latter failed to challenge the authority of the Pecheneg leader Tyrakh. When Tyrakh attacked Byzantine territory and was defeated the emperor decided to settle the subjugated invaders on lands in the region between Sofia and Nish. ${ }^{64}$ These actions were aimed at injecting those areas with a new

\footnotetext{
61 Treadgold, The Byzantine Revival, pp. 282-283, 297-305, 312-325.

62 Treadgold, Byzantium and Its Army, p. 111.

63 Garsoian, "The Problem of Armenian Integration into the Byzantine Empire", pp. 109-113. On Armenian mobility, cf. the chapter of Johannes Preiser-Kapeller in this volume.

64 Angold, The Byzantine Empire 1025-1204, p. 15.
} 
productive and taxpaying population whence the imperial power could recruit soldiers for its armies. Indeed, in 1048 the emperor raised a force of 15,000 among the new settlers and sent them to the eastern front to fight the Seljuks. This policy did not prove successful, however, since the Pechenegs mutinied and returned to the Balkans where they started an uprising against the imperial power that resulted in them becoming autonomous in the areas of their settlement. 65

Later in the reign of Emperor Constantine $\mathrm{x}$ Doukas (1059-1067) groups of Ouzes and Pechenegs were given lands in Macedonia, thus being fully integrated into provincial society and state structures, whereas Emperor Alexios I Komnenos (1081-1118) also took advantage of his great victory at the battle of Levounion in 1091 against a large Pecheneg army that had invaded Byzantine territory in order to settle the invaders on Byzantine soil. According to the chronicler Zonaras, the Pechenegs were given land for settlement with their families and animals in the region of the province of Moglena. A part of them was enrolled in the Byzantine army, forming a distinct unit. ${ }^{66}$

\section{Conditions and Realities of Migration}

Byzantine sources provide a lot of information on the movement of peoples and groups within the empire but they are usually less informative when it comes to the actual conditions of migrating, that is, the means by which people were relocated, the difficulties encountered in the course of the movement as well as the processes of integration of groups of migrants in their new areas of settlement. In the majority of cases, we find just a simple reference to the event of the relocation from one place to the other without any further information about how this took place or how it was experienced by the people involved in it. However, one may combine the little relevant evidence from many different reports in an effort to come closer to the reality of forced or impelled migration in the medieval East Roman Empire.

To begin with, the sources often do not provide numbers for the people that moved and when they do, their accuracy cannot be taken for granted. One may argue that the numbers given for military contingents that migrated may be closer to reality, since in this case we may assume that the receiving state had an interest to register the exact number of people involved. On the other hand, the number of refugees from war zones is impossible to estimate. Moreover,

$65 \quad$ Ibid. pp. $15^{-17}$.

66 Zonaras, Epitome, ed. Dindorf, vol. III, pp. 740-741. 
the modes of travel for the migrating groups are not always specified but can be assumed. For instance, when Nikephoros I ordered the relocation of a large number of Roman subjects from their homes in western Anatolia to Greece we can be pretty certain that such a relocation took place by land and sea, since the people involved obviously needed to reach a port on the western coast of Asia Minor where they could be boarded on ships that carried them to Greece.

According to Theophanes the Confessor, the relocation had a forced character since the migrating population was unhappy about the perspective of abandoning its homelands. ${ }^{67}$ Whether the author's statement reflects the truth or it is a mere product of his bias towards emperor Nikephoros I cannot be said with certainty. It seems plausible, though, that the people involved in the transfer had good reasons not to be fond of the idea of abandoning their homes and selling their properties in order to relocate to a distant and unknown region. ${ }^{68}$ This raises the issue of the role of the imperial state's military power in coercing subject populations to undertake internal migration. Even though the sources do not explicitly mention the activity of the army in this case, it is difficult to imagine how such an enterprise could have taken place without the active role of military forces and the implicit threat of exercising violence against those that would refuse to follow the orders of the imperial centre.

The complexity and difficulty of such a task is obvious and we can get an idea of that by drawing information from other cases. For instance, the deportation of large numbers of Armenians and Syrians under Constantine $v$ in the mid-8th century certainly took place under the supervision of the military units that were involved in the emperor's campaigns in those areas. In this case, the army was responsible for both forcing the mentioned populations to leave their homelands as well as for their safe transfer to Thrace. The fact that due to the internal situation in the caliphate the danger of a Muslim force tracking the convoy on its way into Byzantine territory was very low facilitated the dangerous enterprise of moving such a large number of people by land for such a large distance. An approximate estimation shows that for the population of Melitene to be relocated to Thrace in the area of Adrianoupolis, for instance, a journey by land would take more than 44 days in summer time, according to the regular pace of movement of an army. The shortest itinerary

67 Theophanes, Chronographia, ed. de Boor, p. 486.

68 In Byzantine conception people coming from another region as well as from abroad were regarded as ksenoi or eksōtikoi (strangers, foreigners) - a notion obviously related to the fact that local identity was the strongest, cf. Ahrweiler, "Byzantine Concepts of the Foreigner", p. 2. 
being through Sebasteia, Tabia, Ancyra, Nicaea, Nicomedia, Constantinople, Perinthus and finally Adrianoupolis. ${ }^{69}$

The report of Anna Komnena on the deportation of populations from the region of Philomelion in central Anatolia in the early 12th century offers an insight into the difficulties of a long-distance move of a large number of civilians accompanied by army forces. Emperor Alexios withdrew from Philomelion taking a large number of war prisoners as well as parts of the local Christian population with him. The latter willingly sought to emigrate by taking advantage of the imperial army's presence. ${ }^{70}$ The author describes how the convoy was safely organized by the army in terms of following the rules of a military formation so that the soldiers were able to defend the civilians against harassing Turkish forces. Moreover, she reports that the tempo of the march was much slower than usual due to the fact that this was not a purely military force on the move anymore due to the presence of women and children as well as of pregnant and sick that needed special help or rest. As a result, there were people who lost their lives on the way. ${ }^{71}$ Despite the report's literary character with the biblical motif of Moses lurking behind Alexios' image as an ideal emperor that guided his people to liberty, this certainly entails a true core regarding the dangers that the relocation of a large number of civilians under such circumstances brought with it.

These dangers are made evident in the reports of other authors. For instance, in the case of the forced migration of the Cypriots to Cyzicus under Justinian II Theophanes states that a number of the migrants drowned in the sea due to bad weather. ${ }^{72}$ Moreover, it goes without saying that forced migration in the form of deportation of enslaved populations by enemy forces entailed the greatest of dangers and difficulties for the people that were carried away from their homeland, either for a longer period of time or permanently. The most informative text in this respect is the narration of John Kameniates about his own experience as a member of the population of Thessaloniki that was captured by the Arabs in 904 and was carried by sea to Tripolis in Syria and from there to Tarsus in Cilicia. ${ }^{73}$ The author reports on his fate as a long-time war prisoner, his separation from his wife and children that had managed to escape slavery, as well as on the death of his father in Tripoli where they had

69 The estimation was made according to the orbis Stanford Geospatial Network Model of the Roman World.

$70 \quad$ Anna Komnene, XV 4, 9, ed. Reinsch/Kambylis, p. 470.

71 Ibid. Xv 7, 1-2 ed. Reinsch/Kambylis, p. 473.

72 Theophanes, Chronographia, ed. de Boor, p. 365 .

73 On the text and the debate regarding its authenticity, see Frendo/Fotiou, John Kaminiates, pp. xxxvii-xxxix. 
been transported together. ${ }^{74}$ Moreover, he refers to the sufferings of the prisoners whose main hope was to become part of a prisoners exchange between the empire and the caliphate in order to return home, with many of them being doomed to die of illness while in captivity. ${ }^{75}$

If the main fate of prisoners of war was slavery or death due to the hardships they had to endure, forced migration of groups within the boundaries of the empire was also not less adventurous or hazardous. The life of St Luke of Steiris provides a relevant insight. The saint's ancestors not only had to migrate twice because of the raids of the Muslims but they were also not received well in the final place of their resettlement, the village Kastorion. According to the biographer of the saint, the locals were hostile towards the newcomers and tried to displace them. This motivated the grandfather of the saint to travel to Constantinople, where he managed to receive a hearing from the emperor who granted him imperial letters that ordained the division of lands in the village between the newcomers and the locals. ${ }^{76}$ Choniates is also explicit in his report regarding the bad treatment of his family and all other refugees from Constantinople by the population of the area of Selymbria where they resettled after the sack of the city in April 1204. According to the author, the locals taunted the Constantinopolitan refugees and instead of showing solidarity and support to them as Roman compatriots, they were rejoicing in their sufferings while taking advantage of the situation in order to buy at very low prices what the refuges had to offer for sale. ${ }^{77}$

In spite of the hardships of relocation, refugees as well as deported populations were more often than not able to grow roots in their new areas of settlement. A good example are the Paulicians who were transferred to Thrace from the East under Emperor John I Tzimiskes (969-976) in the 1oth century. More than one century later in the reign of Alexios I Komnenos (1081-1118), the sources testify to the existence of a thriving Paulician community in Thrace, which the emperor decided to persecute for religious reasons. Nonetheless, it is evident that these migrants had not only been able to maintain their heretical beliefs in their new region of settlement for over a century, but were also fully integrated as a distinct ethno-religious group into provincial and state structures as a landowning and taxpaying subject population, wherefrom the imperial power drew recruits for its armies. ${ }^{78}$

74 John Cameniates, De expugnatione Thessalonicae, ed. Böhlig, pp. 73, 10-11 and 78, 7 .

75 Ibid. 78, 8-9.

76 Life of St Luke, ed. Sophianos, p. 6.

77 Choniates, Historia, ed. van Dieten, pp. 593-594.

78 Anna Komnena, Alexias, IV 4,3 and vi 2, ed. Reinsch/Kambylis, pp. 127, 170-171. 
Skylitzes provides a relevant insight concerning prisoners of war that had been relocated during the long-drawn conflict between Samuel and Emperor Basil II. After taking control over the areas of Pelagonia, Prespa, and Ohrid at the core of Samuel's kingdom, the emperor allowed those Roman and Armenian soldiers that had been settled there as captives of the Bulgars and wished to remain to do so. ${ }^{79}$ Choniates also reports on the good treatment of Roman captives by the Turkish ruler Kaykushraw in 1198. The latter deported a large number of Romans $(5,000$ according to Choniates) from cities of the Meander valley and resettled them to Philomelion. There, they were given fertile lands which they were allowed to cultivate free of taxation for a certain period of time. According to the author, this humane attitude of the Turkish ruler towards the deported Roman populations made them forget their homelands, whereas it motivated other Romans to migrate to this area as well. ${ }^{80}$

The successful integration of migrants into their new area of settlement becomes better evident through some well-known cases of certain individuals. The life of St Antony the Younger is a case in point, since the saint was actually a migrant who relocated along with a group of other Christians from the Caliphate (Palestine) to imperial territory in the region of Attaleia (southwestern Anatolia) in the early-gth century. ${ }^{81}$ The reasons that motivated those Christians to migrate are not made clear in the text, but Antony's biography provides an excellent insight into how migrants, especially those that were Chalcedonian Christians and had a knowledge of Greek, could swiftly become full members of the Byzantine society and advance socially. After his resettlement, Antony managed to network with the local powerful who intervened for his ordainment as sub-governor of the theme Kibyrrhaioton by Emperor Michael II. ${ }^{82}$

Foreign groups that were not Chalcedonian Christians or native Greekspeakers also had fair chances for integration and social advancement. For non-Christian groups baptism was the main means of swift social integration, as demonstrated by the reference of Attaleiates to groups of Ouzes and Pechenegs who were settled on imperial soil. Members of these groups had eventually the opportunity to receive high-ranking titles and enter court elite under Emperor Constantine $\mathrm{x} .{ }^{83}$ The Armenian magnates that migrated to eastern Anatolia from the late-11th century onwards, also represent indicative cases of

79 Skylitzes, Synopsis, ed. Thurn, p. 363.

80 Choniates, Historia, ed. van Dieten, pp. 494-495.

81 Life of St Antony the Younger, ed. Papadopoulos-Kerameus, p. 193.

82 Ibid. p. 194.

83 Attaliates, Historia, ed. Perez-Martinez, p. 66. 
non-Chalcedonian and non-Greek-speaking Christians that were able to become part of imperial provincial society, with their prominent members making careers in the empire's provincial administration. These groups were able to maintain their distinct religious and cultural identities in their new area of settlement while acquiring a full-blown status of Roman imperial subjects. ${ }^{84}$

\section{Bibliography}

\section{Primary Sources}

Al- Balādurī, The origins of the Islamic state: being a translation from the Arabic accompanied with annotations geographic and historic notes of the Kitâb Futûh al-buldân, by Ph. Khûri Hitti, New York 1916.

Anna Komnene, Alexias, eds. D.R. Reinsch/A. Kambylis, Anna Comnenae Alexias (Corpus Fontium Historiae Byzantinae XL/1), Berlin 2001.

Attaleiates, Historia, ed. Inmaculada Pérez Martín, Miguel Ataliates, Historia, Madrid 2002.

Bar Hebraeus, The Chronography of Gregory Abû'l Faraj commonly known as Bar Hebraeus, ed. and trans. E.W. Budge, London 1932.

Choniates, Historia, ed.J van Dieten, Nicetae Choniatae historia, pars prior (CFHB 11.1), Berlin 1975.

Chronicle of Monemvasia, ed. I. Dujcev, Cronaca di Monemvasia (Testi e Monumenti 12), Palermo 1976.

John Cameniates, De expugnatione Thessalonicae, ed. G. Böhlig, Ioannis Caminiatae de expugnatione Thessalonicae (Corpus Fontium Historiae Byzantinae. Series Berolinensis 4) Berlin 1973.

Leon Diakonos, Historia, ed. Ch.-B. Hase, Leonis diaconi Caloënsis historiae libri decem (CSHB), Bonn 1828.

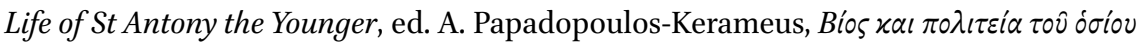

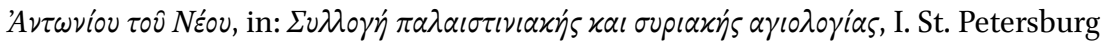
1907.

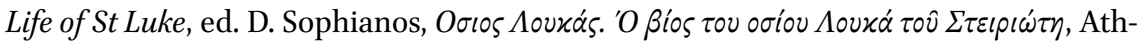
ens 1989 .

Nikephoros, Short History, ed. C. Mango, Nicephori archiepiscopi Constantinopolitani Breviarium historicum de rebus gestis post imperium Mauricii (Corpus Fontium Historiae Byzantinae 13), Washington, D.C. 1990.

Odo of Deuil, De profectione Ludovici VII in orientem, ed. V.G. Berry, New York 1948.

84 Garsoian, "The Problem of Armenian Integration into the Byzantine Empire", pp. 110-112. 
Skylitzes, Synopsis, ed. J. Thurn, Ioannis Scylitzae synopsis historiarum (CFHB 5), Berlin 1973.

The Life of Saint Nikon, text, translation and commentary by D.F. Sullivan, Brookline, MA 1987.

The History of al-Tabari, vol. xxIv: Incipient Decline. The Caliphates of Al-Wathiq, AlMutawakkil, and Al-Muntasir, transl. J.L. Kraemer, Albany 1989.

The History of al-Tabari, vol. xxxii: The Reunification of the 'Abbasid Caliphate: The Caliphate of al-Ma'mun A.D. 813-833/A.H. 198-218, transl. C.E. Bosworth, Albany 1987.

The Seventh Century in the West-Syrian Chronicles, introd., transl. and annotated by A. Palmer. Including two seventh-century Syriac Apocalyptic Texts, introd., transl. and annotated by S. Brock with added Annotation and an historical Introduction by R. Hoyland, Liverpool 1993.

Theophanes, Chronographia, ed. C. de Boor, Leipzig 1883.

Zonaras, Epitome, ed. L.A. Dindorf, Ioannis Zonarae epitome historiarum, vol. III, Leipzig 1868.

\section{Secondary Literature}

Ahrweiler, H., "Byzantine Concepts of the Foreigner", in H. Ahrweiler/A. E. Laiou (eds), Studies on the Internal Diaspora of the Byzantine Empire, Washington, DC 1998.

Anagnostakis, I./Kaldellis, A., "The Textual Sources for the Peloponnese, A.D. 582-959: Their Creative Engagement with Ancient Literature", Greek, Roman, and Byzantine Studies 54 (2014), 105-135.

Angold, M., The Byzantine Empire, 1025-1204: A political history, London 1984.

Beihammer, A.D., Byzantium and the Emergence of Muslim-Turkish Anatolia, ca. 1040-1130, London/New York 2017.

Brubaker, L./Haldon, J., Byzantium in the Iconoclast Era, c. 680-850: a History, Cambridge 2011.

Charanis, P., "The Chronicle of Monemvasia and the Question of the Slavonic Settlements in Greece", Dumbarton Oaks Papers 5 (1950), 141-166.

Charanis, P., "The Transfer of Population as a Policy in the Byzantine Empire", Comparative Studies in Society and History 3/2 (1961), 140-154.

Codoñer, J.S., The Emperor Theophilos and the East, 829-842: court and frontier in Byzantium during the last phase of iconoclasm, Farnham 2014.

Ditten, H., Ethnische Verschiebungen zwischen der Balkanhalbinsel und Kleinasien vom Ende des 6. bis zur zweiten Hälfte des 9. Jahrhunderts, Berlin 1993.

Fowden, G., Empire to commonwealth: consequences of monotheism in late antiquity, Princeton, NJ, 1993.

Frendo, D./Fotiou, A., John Kaminiates. The Capture of Thessaloniki, Perth 2000.

Garsoïan, N. G., The Problem of Armenian Integration into the Byzantine Empire, in H. Ahrweiler/A.E. Laiou (eds.), Studies on the Internal Diaspora of the Byzantine Empire, Washington, DC 1998, pp. 53-124. 
Haldon, J.F., Byzantium in the Seventh Century: The transformation of a culture, Cambridge 1990.

Haldon, J.F., The Palgrave Atlas of Byzantine History, Basingstoke 2005.

Haldon, J.F., "A context for two 'evil deeds': Nikephoros I and the origins of the themata”, in O. Delouis/S. Métivier/P. Pagès (eds), Le saint, le moine et le paysan. Mélanges d'histoire byzantine offerts à Michel Kaplan, Paris 2016, pp. 245-266.

Haldon, J.F., The Empire that would not die. The Paradox of East Roman survival, 640-740, Cambridge 2016.

Kaegi, W.E., Byzantium and the early Islamic Conquests, New York 1992.

Kaegi, W.E., Heraclius, Emperor of Byzantium, Cambridge 2003.

Lilie, R.-J., Die byzantinische Reaktion auf die Ausbreitung der Araber : Studien zur Strukturwandlung des byzantinischen Staates im 7. u. 8. Jhd. (Miscellanea Byzantina Monacensia 22), Munich 1976.

Lilie, R.-J., "Zur Stellung von ethnischen und religiösen Minderheiten in Byzanz: Armenier, Muslime und Paulikianer", in W. Pohl/C. Gantner/R. Payne (eds), Visions of Community in the Post-Roman World: the West, Byzantium and the Islamic world, 300-1100, Farnham 2012, pp. 301-316.

McCormick, M., “The Imperial Edge: Italo-Byzantine Identity, Movement and Integration, A.D. 650-950", in H. Ahrweiler/A. Laiou (eds), Studies on the internal diaspora of the Byzantine Empire, Washington, DC 1998, pp. 17-52.

Oliver-Smith, A./Hansen A., "Involuntary migration and resettlement: causes and contexts", in A. Hansen/A. Oliver-Smith (eds.), Involuntary Migration and Resettlement: The Problems and Responses of Dislocated People, Boulder, CO, 1982, pp. 1-9.

Rotman, Y., Byzantine Slavery and the Mediterranean World, transl. by Jane Marie Todd, Cambridge, Mass. 2009.

Simpson, A., Niketas Choniates: A historiographical study, Oxford 2013.

Stouraitis, Y., "Reinventing Roman ethnicity in high and late medieval Byzantium", $M e$ dieval Worlds 5 (2017), 70-94.

Treadgold, W., The Byzantine Revival: $780-842$, Stanford 1988.

Treadgold, W., Byzantium and Its Army, 284-1081, Stanford, California 1995.

Vryonis, S., The decline of Medieval Hellenism in Asia Minor and the process of Islamization from the eleventh through the fifteenth century, Berkley/Los Angeles/London 1971.

Woods, D., "Corruption and Mistranslation: The Common Syriac Source on the Origin of the Mardaites", published online: http://www.syriacstudies.com/AFSS/Syriac _Articles_in_English/Entries/2011/1/9_Corruption_and_Mistranslation_The_Com mon_Syriac_Source_on_the_Origin_of_the_Mardaites_David_Woods.html. 